\title{
DOES BUKITTINGGI NEED AN AIRPORT?
}

\author{
Prima Saputra1, Wike Arinda Putri' ${ }^{2}$, Basri Fahriza ${ }^{3}$ \\ 1. STMT Trisakti, 2. STMT Trisakti, 3. STMT Trisakti \\ $\triangle$ corresponding author: prima.saputra38@gmail.com
}

\begin{abstract}
Building a new airport in Bukittinggi becomes necessity to support tourism industry in west Sumatera and strengthen Bukittinggi as tourist destination. Eventhough the distance from Minangkabau International Airport to Bukittinggi is 72 $\mathrm{km}$, the route and traffic condition have made the time to reach Bukittinggi about 2.5 hours on regular day but in holiday season the travel can take 10 hours. To analyze the problem we used SWOT and IFE and EFE to find the result of the discussion.

Keywords: Bukittinggi, Airport, Transportation, Tourism, Infrastructure
\end{abstract}

\section{Introduction}

Transportation infrastructure is a key element for the development of tourist destination (Rai, 2017) . An airport is not only as infrastructure function but also as a supporting facilities of tourism sector. An air transport is able to move faster than other transportation and has a straight path with barrier free (Setiani, 2015). An airport can help reducing land transportation problems and can be an alternative in solving various problems which caused by land transportation. The tourism itself can bring so many impacts on the transportation, social, economy, etc. Tourism has become one of the fastest growing economic sectors in the world (Ferreira \& Dias, 2015).

Bukittinggi is a city in West Sumatera Province and it has become a tourism icon in Indonesia since 33 years ago. Bukittinggi offers plenty of tourism attractions that attract tourists who come to its area. The area surrounded by two mountains, they are Singgalang and Merapi. Currently travelling from Minangkabau airport which is located in Padang pariaman regency to Bukittinggi takes about 2.5 hours in week days non peak season of holiday base on observation through Google maps from October $10^{\text {th }}$ to November $10^{\text {th }} 2017$ and personal experience for more than 15 years. "Tourism is one of the main things that can be sold to both local and foreign tourist. The 
tourism from year to year of course need to be reformed so that the existence of tourist attractions continue to play an important role in increasing tourist visits," (Agustino, 2017).

\section{Method}

This research focus on finding the necessity of building an airport in Bukittinggi to increase the number of tourist in Bukittinggi area. There are reasons why Bukittinggi needs an airport to facilitate the tourist access this city and gain more tourists visiting this area. One of the reasons is travelling time from the airport to the city is unpredictable due to traffic and route condition. This research found there are good impacts given by a presence of an airport in this city. This paper only discussed about the impacts of building an airport in increasing the number of tourists visiting Bukittinggi. SWOT is used to analyze the necessity of building an airport in Bukittinggi. To get the conclusion, we used Internal Factor Evaluation (IFE) and External Factor Evaluation (EFE) with the Total IE Matrix as the final result. This research used primary and secondary data through an observation, literature study and statistic data.

\section{Discussion and Result}

A. Strength

Bukittinggi is famous as Tourism top destination with plenty of tourism places and attraction. The city offer variety of attractions with its natural beauty, historical site and unique heritage and cultural. The three main attractions of the city is Jam Gadang, this is an icon of this city which look like Big Ben in London and it is the main attraction among the tourists. Another tourist area is Lobang Jepang, the historical tunnel as the legacy from Japan occupation era which located in Panorama Park area. Beside two man-made tourist attraction, Bukittinggi has Ngarai Sianok or Sianok Canyon to show the natural beauty of the city to the tourist. 
Bukittinggi situated in strategic area, located in the middle of Trans Sumatera route, it connected to major cities in Sumatera such as Pekanbaru and Medan. Beside that, Bukittinggi surrounded by another cities and regency in West Sumatera. Agam is the closest neighbor of Bukittinggi which has several famous tourism attractions, they are Maninjau lake and Lawang Park. Payakumbuh city located $32.5 \mathrm{~km}$ from Bukittinggi, this city also has some attractive places such as Lembah Harau and Kelok Sembilan. Other city that close to Bukittinggi is Padang Panjang which famous with the Minangkabau Cultural Center. Tanah Datar regency, Pasaman, Pasaman Barat, Lima Puluh Kota regency are the other close area to Bukittinggi.

Culinary tour is a favorite activity enjoyed by the tourist during their vacation. Quan and Wang (2004) Culinary is the main motivation and is an added value to the image of a destination (M, 2011). Bukittinggi as a tourism city well known by their unique and tasty Minang cuisine. Nasi Kapau, this food will completely pleased your mouth when you eat it, the strong and unique taste is the power of this food. Kerupuk Sanjai, this is a famous traditional snack from Bukittinggi. Ampiang Dadiah, if you enjoy the beverage that made of milk, this one is the best option when you come to Bukittinggi, it's a traditional yoghurt made from a fermentated buffalo's milk. Ketupat kapau is different from the other ketupat in Indonesia, it consists of some vegetables that other ketupat doesn't have.

Bukittinggi has a good infrastructure that comparable to other big cities in Indonesia. There are six hospitals, three of them are government hospital (Bukittinggi, 2015a). Achmad Mochtar hospital is the largest hospital while Ibnu Sina hospital is the most popular one among the residence. Bukittinggi has some excellent hotels to provide tourist need with 66 hotels consist of and 48 non star hotels and 18 star hotels which have been built since 2014. Together with the increasing of hotels, the number of 
guests in Bukittinggi had increased to 333,127 people in 2014 which consisted of Local and International tourists (Bukittinggi, 2015b). Bukittinggi also well known for its trade center. There are some markets that famous among the tourists. Aur Kuning market is the largest grocery market in West Sumatera. This market is also known as Tanah Abang market in Bukittinggi. Pasar Lereng is famous for its street vendors and in pasar lereng also there is los lambuang that very famous for its nasi kapau. Beside those two markets, there are also Pasar Atas and Pasar Bawah.

As the main gate of the tourism to Bukittinggi, Minangkabau is the only airport that serves the tourists who came by air transportation. The distance from Minangkabau airport to Bukittinggi is $72,7 \mathrm{~km}$ and it usually takes 2 hours and 30 minutes by the land transport, since the road condition is complicated/tortuous it takes longer than it usual time travel to achieve the same distance in other area. This situation makes some tourists feel uncomfortable to visit Bukittinggi.

\section{B. Weakness}

Bukittinggi's earth surface level is not equal. It's wavy and hilly. This condition cause it hard to built an airport because it needs a large flat area to build the runway. But there is a potential area in the eastern Bukittinggi to build an airport. Bukittinggi is a beautiful small city, this city area is only $25.24 \mathrm{~km} 2$. It becomes a problem about where to build the airport later because the central part of the city was very crowded, but there is any potential area to build the airport in the Eastern side of the city. In the future, this city hoped can be the Indonesia's Singapore, even the areas size was very small but yet it can attract so many tourist. Later the government can adopt the Singapore's strategies in marketing their tourism through telling a great Bukittinggi story, targeting the right fans, and enhancing the delivery (Board, 2016). 


\section{Oppurtinity}

Air transport industry and tourism are complemented each other. Tourism depends on transportation to bring visitors, whilst the transportation industry depends on tourism to generate demand for its services (Ricardianto, Djajaputra, Martono, \& Introduction, 2017). The most important role of tourism destination is the transportation. Tourism can't develop without the availability of transportation. Especially, transportation through the air. The availability of safe and affordable transportation to tourist attraction can effect on tourism growth (Universitas, Tantular, \& Tourism, 2009). To access the location, we need transportation which can help us reach the destination through convenient access. Up to 2006 the government attention has been focused on generating more domestic tourism. Competition amongst budget airlines has increased the number of air travelers throughout the country (Ricardianto et al., 2017). Provision of transportation facilities and infrastructure to tourist attraction must be perfectly planned, so it can attract tourists.

There are impacts of transportation to the local tourism. People who use public transportation to travel and leisure will create a new group of potential consumer to the local accommodation, culinary, and tourism service. Public transportation will bring the economic benefits to the tourism and entertainment sector in the area. (Universitas et al., 2009). A presence of an airport in Bukittinggi will bring more possibility to attract the International tourist. The appearance of an airline that is a member of an alliance, will increase the passengers flow by a new service that would not have been possible without the code share/alliance (Fahriza, 2005).

The population in Bukittinggi and surrounding area is a big potential to build an airport in Bukittinggi. Based on 2015 BPS's data, the total amount of population in Bukittinggi and the cities around it are 2.172.214. This 
total amount of population can be a very good opportunity to build an airport in Bukittinggi, so the people from and to the destinations around Bukittinggi will prefer to use the new airport instead of the existed one since the distance problem.

Building an Airport in Bukittinggi will be supported by the neighbor government because payakumbuh city council reviews the plan to build an airport in their area. But, the city principal will fully support the building an airport in the neighbor city (Supratiwi, 2013).

As West Sumatera province is one of the area with the high potential of the natural disaster like Tsunami, Earthquake, Land slide, etc. West Sumatera needs a backup point to be the center of distribution of help when the disaster happen. Bukittinggi as the second big city in West Sumatera seems to be the best place to be built as an alternative airport when the disaster happen and impact the existing airport

Bukittinggi will expand the area by putting some of the Agam Regency area to their territory. Later Bukittinggi expected to have 7 districts with 58 sub districts and the width of the area will become $145.299 \mathrm{~km} 2$. The airport and freight terminal are completed by the facility that has three distinct functions (Ashford and Wright 1992) (Moore, 1997), that are : Change of Mode. If this airport is operated, people who will come to Bukittinggi no longer need to use land transportation to reach their destination. To provide the necessary facilities for ticketing, documentation, and controlling the passengers and freight; Change of Movement Type. To convert continuous arrivals of freight by trucks and of departing passengers by car and bus which usually used by the people to reach Bukittinggi into aircraft-sized batches that generally depart according to a preplanned schedule : to sreverse this process for arriving aircraft. 
D. Threat

Sumatera lies stretched along $1.900 \mathrm{~km}$ from Banda Aceh until Semangko bay in south Lampung, parallely stretched with subduction zone as influence of convergence. Eurasia Flake with Indo-Australia D. Hilman flake and K. sieh in Neotectonic of The Sumatran Fault Indonesia, 2000 is divided pieces of Sumatra into 3 regions they are north, middle, and south. There are 19 segments based on observation in tophography's map and atmosphere photo. Bukittinggi is in one of the segments, it is sianok segment. Sianok segment has earthquake prone areas. The biggest earthquake was happened on august $4^{\text {th }} 1926$ the strength of the earthquake was 7,3 SR with the broken center among Bukittinggi and D. Singkarak (Ir Ade Edward, 2013). Bukittinggi areas has medium potential for ground movement, flooding, and Landslide. In this zone there is ground movement, flooding and Landslide if rainfall above normal, especially in area adjacent with river valley, cliff path and if the slope is interrupted.

Later, if the railway from Padang panjang - Bukittinggi - Payakumbuh is successfully opened, it can be proof of government to solve traffic jam from Padang to another city in North Part West Sumatera. Bukittinggi society and around of city will be proud if the train is opened and Bukittinggi will be more crowded. Many tourism will come because of the easy transportation, they will not face the traffic jam and parking problem (Bermasa, 2017). But so far, the plan is still a plan.

As Bukittinggi is a tourist area, the toll can be a supporting facility. The vice governor of west Sumatera Nasrul Abit anthusiastically welcomes the addition of toll length plan stage I to Bukittinggi. According to him, the addition of toll is the government's hope since a long time ago, so that the toll can be one of the solutions for travelling from Padang to Bukittinggi which is now there is traffic jam (Ant, 2017). 
Since West Sumatera province already has an international airport, the building of the airport in Bukittinggi will cause a multi airport systems in west Sumatera. Many multi-airport systems already exist, for example, around New York and San Francisco, London and Paris, Tokyo and Seoul. These systems present unique difficulties for airport planners and operators, because the airport systems compete with each other for traffic. so they demand special attention (Odoni, 2003). The development of airport in Bukittinggi will create a multi-airport system that has always been problematic (Odoni, 2003). The analysis based on frequency share has limit. This define the principal conditions that enable Bukittinggi airports to develop.

\section{Discussion and Result}

Table 1.

\begin{tabular}{lllc} 
Key internal factors & Weight & Rating & Weighted Score \\
\hline Strength & & & \\
Tourism Attraction & 0.25 & 4 & 1 \\
Infrastructure & 0.18 & 3 & 0.54 \\
Distance from Existing Airport & 0.14 & 2 & 0.28 \\
& & & \\
Weakness & & & \\
Mountains Area & 0.20 & 3 & 0.60 \\
City Size & 0.23 & 4 & 0.92 \\
\hline TOTAL & 1.0 & & 3.34
\end{tabular}

Table 2.

\begin{tabular}{llll} 
Key external factors & Weight & Rating & $\begin{array}{l}\text { Weighted } \\
\text { Score }\end{array}$ \\
\hline Opportunity & & 4 & 0.68 \\
Increase Amount of Tourist & 0.17 & 4 & 0.60 \\
Increase Income & 0.15 & 2 & 0.16 \\
Total Amount of Population & 0.08 & 1 & 0.06 \\
Supported by Neighbor government & 0.06 & 3 & 0.30 \\
Alternative Airport & 0.10 & 1 & 0.06 \\
Area Expansion Plan & 0.06 & & \\
Threat & & & \\
Natural Disaster & & 4 & 0.52
\end{tabular}


Table 2, cont.

\begin{tabular}{llll} 
Train Construction & 0.09 & 3 & 0.27 \\
Toll Road Building & 0.09 & 3 & 0.27 \\
Overlapping Market & 0.07 & 2 & 0.14 \\
\hline TOTAL & 1.0 & & 3.06
\end{tabular}

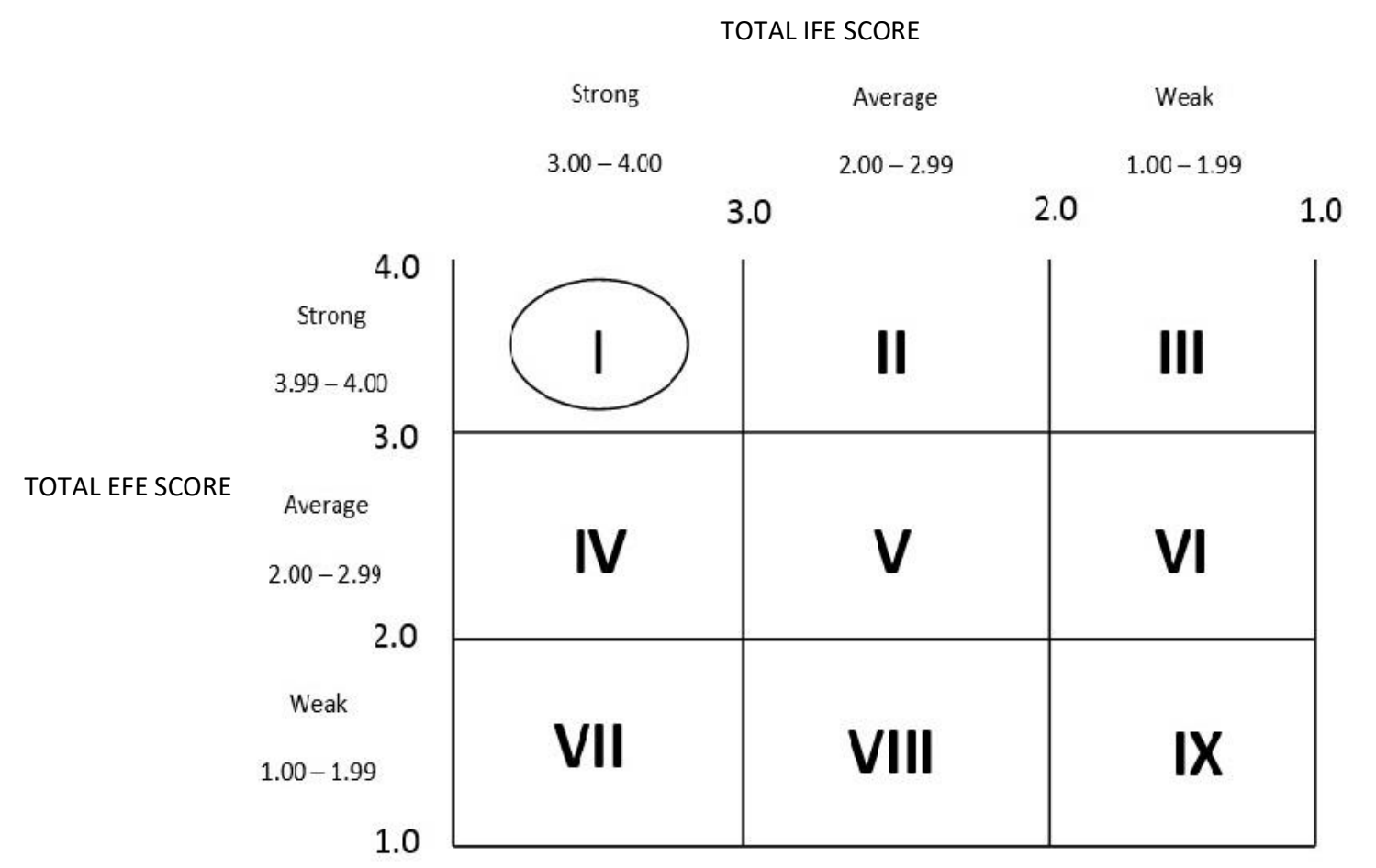

Figure 1.

Table 1 describes about the Internal Factor Evaluation that contained the Strong and Weakness, table 2 discussed about the External Factor Evaluation contained of Opportunity and Threat. The weight total of each factors should be 1.0 and the rating is given based on it is importance. Based on the Internal and External Factor Evaluation in table 1 and 2, we got the result of the discussion in figure 1. Bukittinggi position in IE matrix is in the $1^{\text {st }}$ square which indicated that Bukittinggi has a strong reason to build a new airport. 


\section{Conclusion}

Tourism become one of the fastest growing economic sectors in the world (Ferreira \& Dias, 2015). Building an airport in Bukittinggi will help increasing the tourists. This airport presence will ease the tourist access to Bukittinggi. Based on SWOT analysis, we discovered that Bukitinggi had a strong reasons why they needed to have an airport. Beside the strong reasons, there will be plenty of opportunities they get by operating the airport. So we strongly recommended for Bukittinggi to have their own airport. We also recommend for private sector to support the idea of building an airport in Bukittinggi, by investing in the building project, private sector can earn money from the commercial space later when the airport has already built. However, in this research we only discussed about the necessity of building an airport in Bukittinggi.

\section{References}

Agustino, Y. P. (2017). 33 Tahun Sebagai Kota Wisata, Pemko Bukittinggi Bakal Tingkatkan Promosi dan Pengembangan Objek Wisata. Retrieved October 13, 2017, from http://googleweblight.com/?lite_url=http://rri.co.id/bukittinggi/post/berita/ 370799/daerah/33_tahun_sebagai_kota_wisata_pemko_bukittinggi_bakal_ tingkatkan_promosi_dan_pengembangan_objek_wisata.html\&ei=ILFTx 5b g\&lc=enID\&s $=1 \& \mathrm{~m}=800 \&$ host $=$ www.google.co.id $\&$ ts $=1507886522 \& \operatorname{sig}=$ ANTY _L2wM4m8OduXgKRAiP3xaVbFLPp0JQ

Ant. (2017). Tahap I Tol Padang-Pekanbaru Sampai Bukittinggi, Menteri Rini: Bisa Jadi Penunjang Wisata. Okezone.com.

Bermasa, A. (2017). Pengguna Tanah Kereta Api di Bukittinggi Jangan Kasakkusuk Cari Dukungan Pihak Lain. Kompasiana.

Board, S. T. (2016). MARKETING STRATEGY: of stories, fans and channels.

Bukittinggi, B. K. (2015a). Info Rumah Sakit Kota Bukittinggi.

Bukittinggi, B. K. (2015b). Statistik Perhotelan.

Fahriza, B. (2005). SHOULD GARUDA INDONESIA JOIN THREE MAJOR AIRLINES ALLIANCES : STAR ALLIANCE , 123-139.

Ferreira, B., \& Dias, D. E. S. (2015). World tourism day 27 september 2015.

Ir Ade Edward, Y. A. S. (2013). Peta Bahaya Gempa Bumi Zona Patahan Sumatera, Provinsi Sumatera Barat.

M, N. B. R. (2011). Peranan Transportasi dalam Pariwisata, 15(2), 195-204. 
Moore, N. A. H. P. M. S. C. A. (1997). Airport Operations (Second). United States of America: MC Graw Hill.

Odoni, R. de N. A. (2003). Airport Systems | Planning, Design, and Management. United States of America: MC Graw Hill.

Rai, B. N. (2017). The Support of Surrounding Airports for Borobudur Temple Development as a Top Priority Tourist Destination. WARTA ARDHIA Jurnal Perhubungan Udara, 43(1), 63-78.

Ricardianto, I. P., Djajaputra, G., Martono, P., \& Introduction, I. (2017). Air Transport and Tourism in Indonesia, 10(5), 1-19. https://doi.org/10.9790/5736-1005010119

Setiani, B. (2015). Prinsip-prinsip Pokok Pengelolaan Jasa, 3(2).

Supratiwi, F. (2013). Golkar Tolak Rencana Pembangunan Bandara Payakumbuh. Antaranews.com.

Universitas, D., Tantular, M., \& Tourism, C. (2009). Posisi Transportasi Dalam Pariwisata, (Bps 2008), 39-48. 